\title{
松浦川アザメの瀬の流況特性と 本川への影響について \\ EFFECTS OF FLOOD PLAIN ON MAIN CHANNEL WITH FLOOD FLOW \\ OF THE MATSUURA RIVER
}

\author{
渡邊訓甫 1 ・平川隆一2 \\ Kunitoshi WATANABE and Ryuichi HIRAKAWA \\ 1正会員 工博 佐賀大学教授 理工学部都市工学科（二840-8502 佐賀市本庄町1番地） \\ 2正会員 博（工） 佐賀大学助手 理工学部都市工学科（同上）
}

\begin{abstract}
In the Matsuura river digs the ground in the rice field of Azame down because there were for a long time a lot of floods, makes a flood plain there, and the natural regeneration business that starts restore the marsh is done. In this study, the flow including this Azame was analyzed by the numerical simulation.

As a result of the numerical experiment, it was understood to be suppressed even to about the half when the flood plain existed while flow velocity in the narrow section reached $4.5 \mathrm{~m} / \mathrm{s}$ in the current state without the flood plain river channel at the flow rate peak.

Moreover, the source location of the maximum flow velocity shifted to the left bank neighborhood though the peak at the flow velocity of the main current part in the flood plain downstream edge was suppressed by about $60 \%$ of the current state river channel.
\end{abstract}

Key Words : Flood plain, Flood management, Unsteady flow, Bamboo grove on the bank of a river

\section{1. はじめに}

佐賀県北部を流れる松浦川は，佐賀県杵島郡黒髮山系 に発し，玄界灘に注ぐ幹川流路延長 $47 \mathrm{~km}$, 流域面積 $446 \mathrm{~km}^{2}$ の一級河川である。この川は昔から洪水が多く， 流域の住民は洪水によって多大な被害を受けてきた．研 究対象地であるアザメの瀬は，松浦川河口から $15.8 \mathrm{~km}$ 右岸の相知町佐里下地区に位置し, 面積約6ha, 延長約 $1000 \mathrm{~m}$, 幅約 $400 \mathrm{~m}$ で丘陵に接している.ここも過去年 に1回の割合で洪水被害を受けてきた地区である.アザ メの瀬の治水計画は当初，一部の水田を掘削して川幅を 拡げる計画だった。しかしながら近年，河川の自然再生 事業が日本各地で行われているのに伴い，水田地盤を掘 り下げ，下流部が本川と連結された氾濫原とし，遊水効 果による治水と魚類等の生息環境の場としての汇濫原的 湿地の再生を目指して自然再生事業が進んでいる1), 2). そのため, 湿地内植生の増加も顕著になってきている. また, 汇濫流による流速や底面剪断応力の大きな変動が, 汇濫原内の水位や土砂の輸送に大きな影響を与える可能 性があり，氾濫原の水理学的機能と氾濫域内の流れ構造
を知ることは極めて重要である.

本研究では, 湿地再生による樹木類の増加に伴う抵抗 の増加および竹林の粗度効果に特徵づけられた, 洪水時 の河道と湿地内の流況変化と湿地内の流れ構造を明らか にし，湿地が本川へ与える影響を検討する.

\section{2. 流れのシミュレーション}

現地の流況を把握するために，アザメの瀬を含む区間 について数值解析を行った. 基礎式として，水深方向に 平均したデカルト座標系 $(x, y)$ の連続の方程式と運動 方程式を，長田の方法 ${ }^{3)}$ に基づいて一般座標系 $(\xi, \eta)$ に 変換したものを用いた.

$$
\frac{\partial h}{\partial t}+\frac{\partial M}{\partial x}+\frac{\partial N}{\partial y}=0
$$




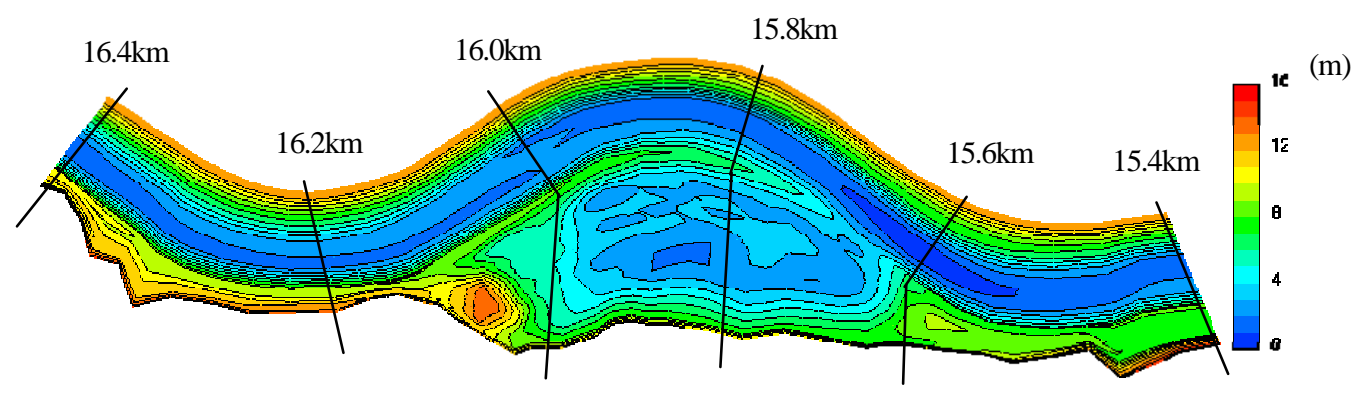

図-1＼cjkstart河床形状(15.4km 16.4km)
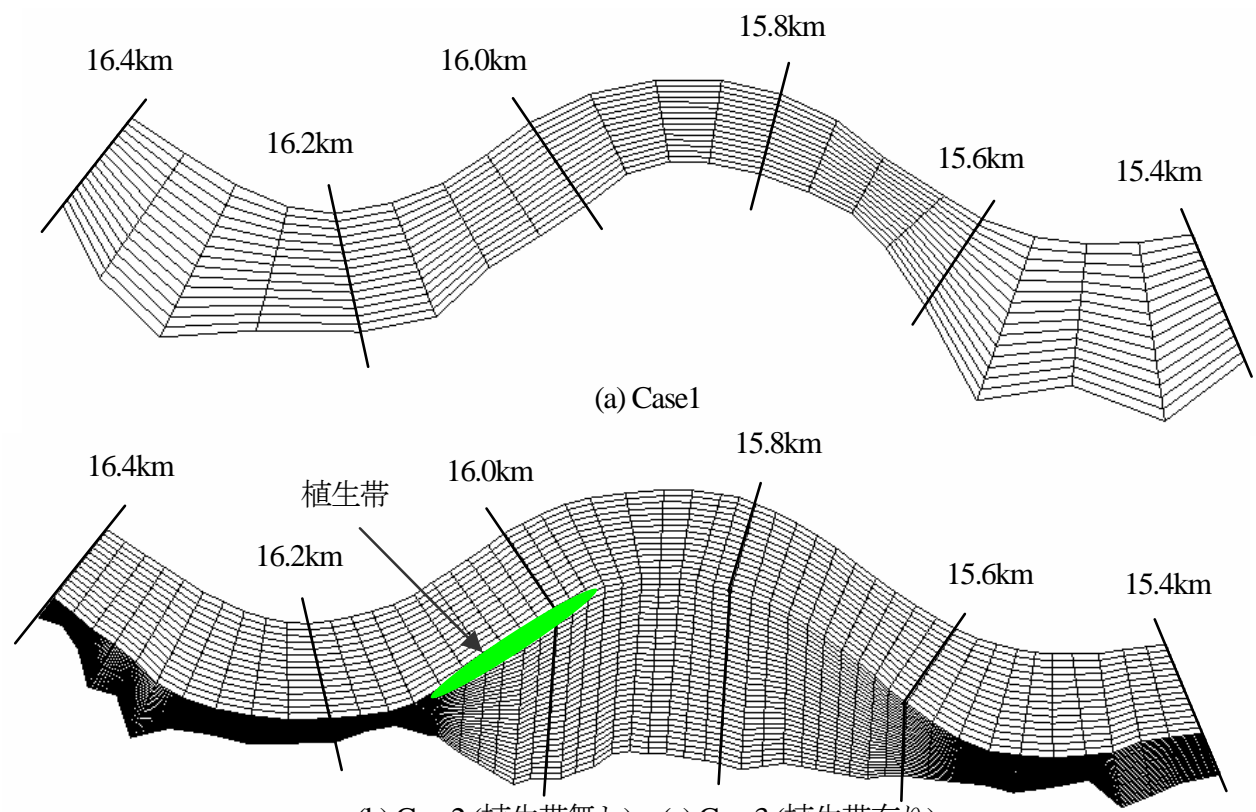

(b) Case2 (植生帯無し), (c) Case3 (植生帯有り)

図-2 計算メッシュ

$$
\begin{aligned}
& \frac{\partial M}{\partial t}+\frac{\partial u M}{\partial x}+\frac{\partial v M}{\partial y} \\
& =-g h \frac{\partial z_{s}}{\partial x}-\frac{\tau_{0 x}}{\rho}+\frac{\partial}{\partial x}\left(-\overline{u^{\prime 2}} h\right)+\frac{\partial}{\partial y}\left(-\overline{u^{\prime} v^{\prime} h}\right) \\
& \frac{\partial N}{\partial t}+\frac{\partial u N}{\partial x}+\frac{\partial v N}{\partial y} \\
& =-g h \frac{\partial z_{s}}{\partial y}-\frac{\tau_{0 y}}{\rho}+\frac{\partial}{\partial x}\left(-\overline{u^{\prime} v^{\prime} h}\right)+\frac{\partial}{\partial y}\left(-\overline{v^{\prime 2}} h\right)
\end{aligned}
$$

ここに, $t$ : 時間, $(x, y)$ : 空間座標, $h$ : 水深, $(u, v): x, y$ 方向の水深平均流速, $(M, N): x, y$ 方 向の流量フラックスである.

また，流れの解析において式(2)中の $\left(\tau_{0 x}, \tau_{0 y}\right)$ は底面 剪断応力と植生抵抗の和であり, 以下のように表す.

$$
\tau_{0 x}=\frac{\rho g n^{2} \overline{u^{2}}}{h^{1 / 3}}+\frac{\rho g h \overline{u^{2}}}{K^{2}}
$$

$$
\tau_{0 y}=\frac{\rho g n^{2} \overline{v^{2}}}{h^{1 / 3}}+\frac{\rho g h \overline{v^{2}}}{K^{2}}
$$

ここに，K：植生の透過係数である．2005年6月に堤防 上に繁茂する竹林の現地調査を行った結果，竹の平均直 径が $2.3 \mathrm{~cm}, 1 \mathrm{~m}^{2}$ ありの本数は52.7本であった。これら の数值を用いて $K=7.31 \mathrm{~m} / \mathrm{s}$ とした. ここで，竹林の 抵抗係数は $1.2^{4)}$ としている.

底面粗度係数は，河道を $n=0.035$, アザメの瀬内を $n=0.045$ とした．これは，計画高水位とほぼ等しくな る值である. 初期水位勾配は平均河床勾配と同等とし, 1/1,000 とした. 計算時間間隔はオイラーの陽的解析法 の誤差を小さくするため $\Delta t=0.01$ 秒とした.

対象区間の河床形状を図-1に示す。河道内は2003年3

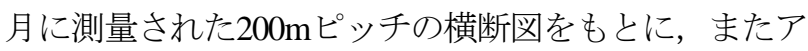
ザメの瀬内は計画平面図に基づいて各格子点に河床デー タを与えている．解析ケースを図-2に示す，流下方向に は，河道のみが200m間隔で21点，アザメの瀬を考慮し た場合が20m間隔で51点，横断方向に46点でメッシュ分 割している. 横断方向は河道とアザメの瀬内で分割し, それぞれ15分割と30分割とした．左岸は堤防肩，右岸は 

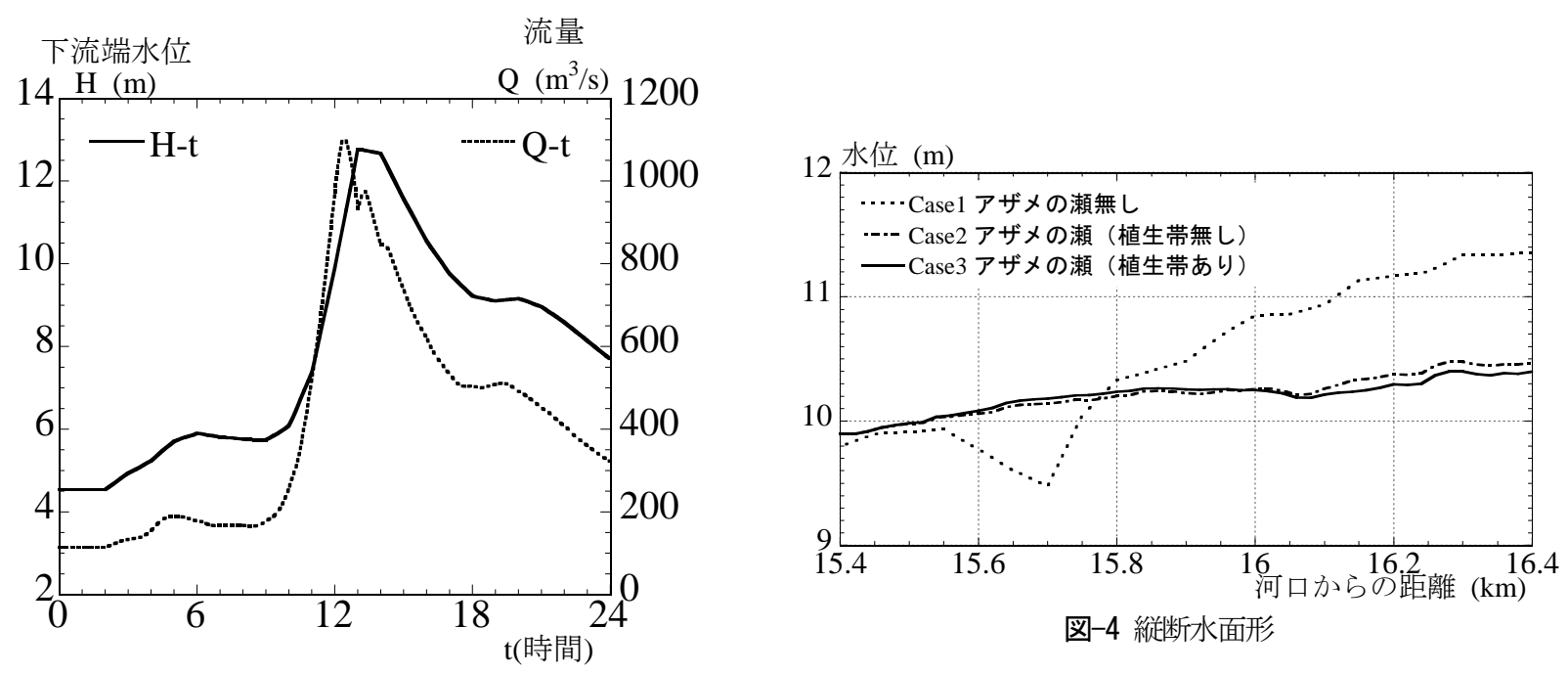

図-3 計画ハイドログラフ



図-5 横断水面形

(アザメの瀬上流部，16.0km）

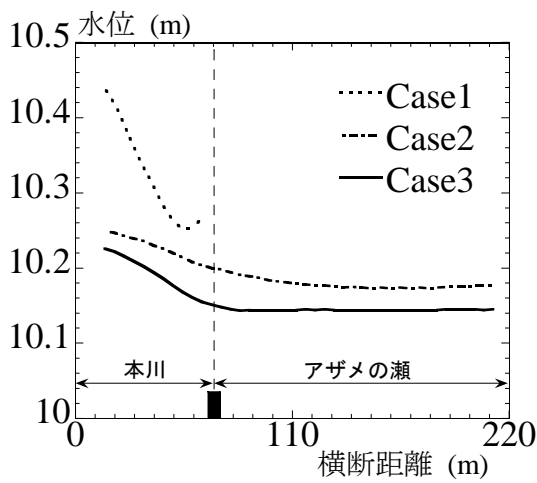

図-6 横断水面形

（アザメの瀬中流部，15.8km)

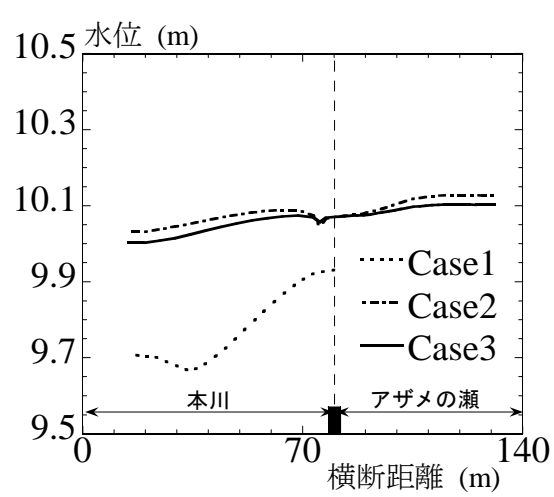

図-7 横断水面形

（アザメの瀬下流部，15.6km）
山の際を境界としている. Case1は河道のみである. Case2およびCase3はアザメの瀬を考慮し，さらにCase3 では2004年3月の竹林分布を用いた.

境界条件として上流端に流量を，下流端に水位を与え 不定流の計算を行った. 解析に用いたハイドログラフを 図-3に示す。これは，松浦川における計画高水流量およ び水位を境界条件として与えて二次元計算を行い，得ら れた $16.4 \mathrm{~km}$ 地点の流量と $15.4 \mathrm{~km}$ 地点の水位である.上 流端のピーク流量は約 $1,100 \mathrm{~m}^{3} / \mathrm{s}$ ，下流端のピーク水位は 約 $13 m$ であり，助走時間として3時間一定の流量と水位 で計算した後，洪水流量と水位の変化を与えた．なお本 論文では，流量ピーク時のみ以下に考察を進める.

\section{3. 解析結果}

\section{(1) 水面形}

図-4 に各ケースにおける流量ピーク時の本川中央部 の縦断水面形を示す. 現況河道のCase1では上流で水位 は上昇し, 流下寸るに従い下降し，15.7km付近で最小 值をとっている. その差は約 $2 \mathrm{~m} に も$ 達している. 上流端
と下流端との差は約 $1.5 \mathrm{~m}$ である.アザメの瀬が存在す るCase2では，上流端の水位はCase1に比べて約 $80 \mathrm{~cm}$ 減 少している．その水位は上流から下流にかけて緩やかに 減少し，水位差は約 $60 \mathrm{~cm}$ である。ささらに，上流部右岸 堤防上に竹林が存在するCase3では, Case2に比べて上流 部で約 $10 \mathrm{~cm}$ 水位低下が見られるが，中流部から下流 間にかけてはほぼ同じ傾向である.

図-5〜7は，アザメの瀬上流(16.0km), 中流(15.8km), 下流(15.6km)における流量ピーク時の水面形の横断分布 を示す，上流部の図-5では，本川の水位が瀬内の水位よ りも高くなっており，本川から瀬内へと向から流れがあ ると考えられる.中流部の図-6でも上流部と同様に本川 から瀬内への流入が有ると考えられる．下流部の図-7で は本川の水位よりも瀬内の水位が高いために，瀬内から 流出していると考えられる. また各断面の水面形に横断 勾配が生じているのは，本川の蛇行の影響であると思わ れる.この横断勾配は，各断面共アザメの瀬が有る方が 現況河道のCase1よりも緩やかになっていることが分か る. 以上の水面形より，アザメの瀬を考慮すると上流川 での水位は現況河道よりも低く抑えられるが，下流の本 川とアザメの瀬の結合地点付近では逆に現況河道の方が 低くなることが示された。 

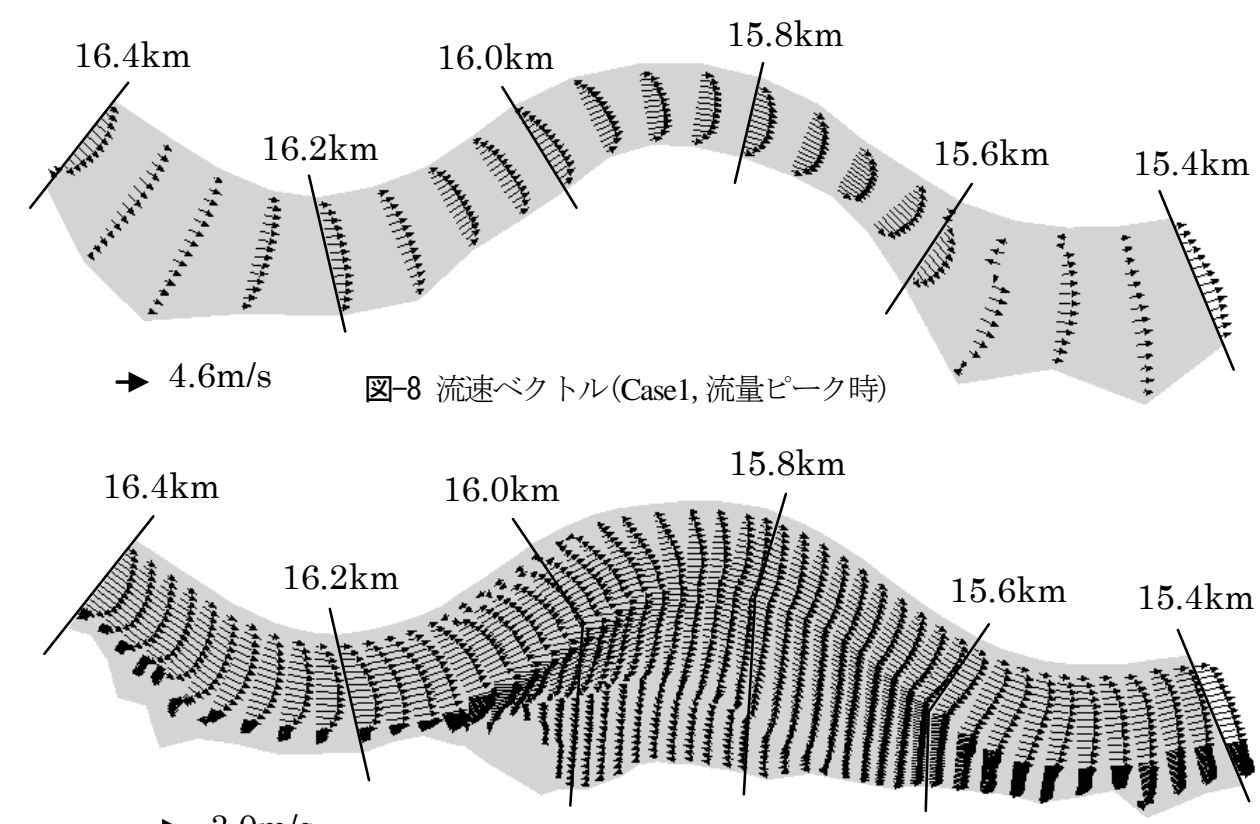

図-9 流速ベクトル(Case2, 流量ピーク時)

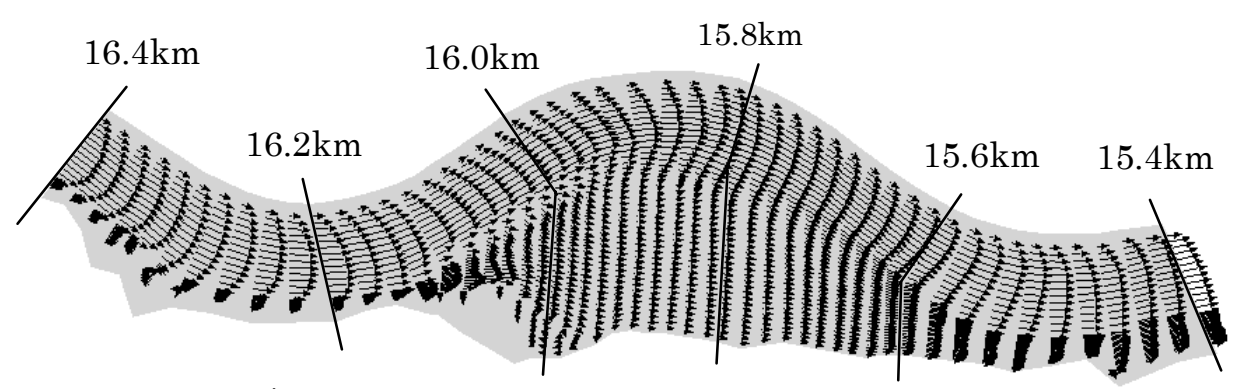

$\rightarrow 3.0 \mathrm{~m} / \mathrm{s}$

図-10 流速ベクトル(Case3, 流量ピーク時)

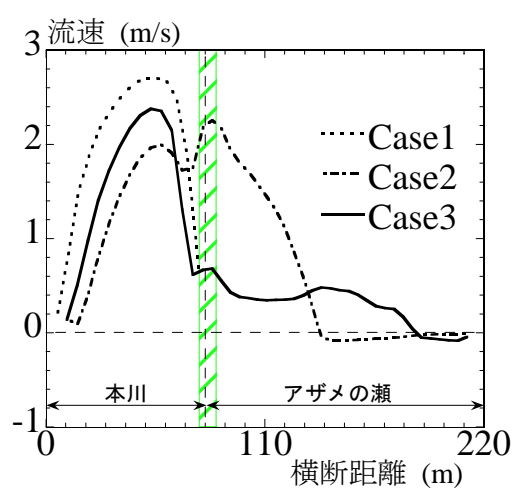

図-11 流速の横断分布 （アザメの瀬上流部，16.0km）

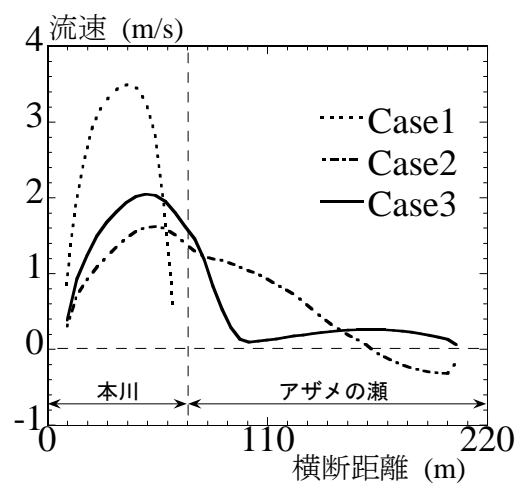

図-12 流速の横断分布 （アザメの瀬中流部，15.8km）



図-13 流速の横断分布 （アザメの瀬下流部，15.6km）

\section{（2）流速分布特性}

各ケースの計画流量ピーク時における流速ベクトルを 図-8〜10に示す. 図-8のCase1は, 約15.7kmの狭窄部で 最大流速を示しており，その大きさは約 $4.5 \mathrm{~m} / \mathrm{s}$ である. その下流の拡幅部においては流速が減少しており, 左岸 付近では逆流が認められる. 図-9のアザメの瀬が存在す るCase2では，16.0〜16.1kmにかけて堤防を乗り越えて 瀬内一と流入寸ることが認められる. 越流した流れは堤
防に沿って流下寸るため，瀬内には大きな一つの循環流 が形成されている. 本川の流速はCase1に比べて減少し ている. 最大流速はアザメの瀬上流端の堤防上であり， その大きさは約 $3 \mathrm{~m} / \mathrm{s}$ である. 図-10のCase3では, アザ メの瀬上流の堤防を越流して瀬内一と流入する流速は, Case2の約1/3にまで抑えられている。 これは堤防上に繁 茂する植生の影響である。 またこの図より，流量ピーク 時に瀬内一と流入した流れは循環流を形成することなく， 横断方向にほぼ一様な流速で流下寸ることが分かる。こ 


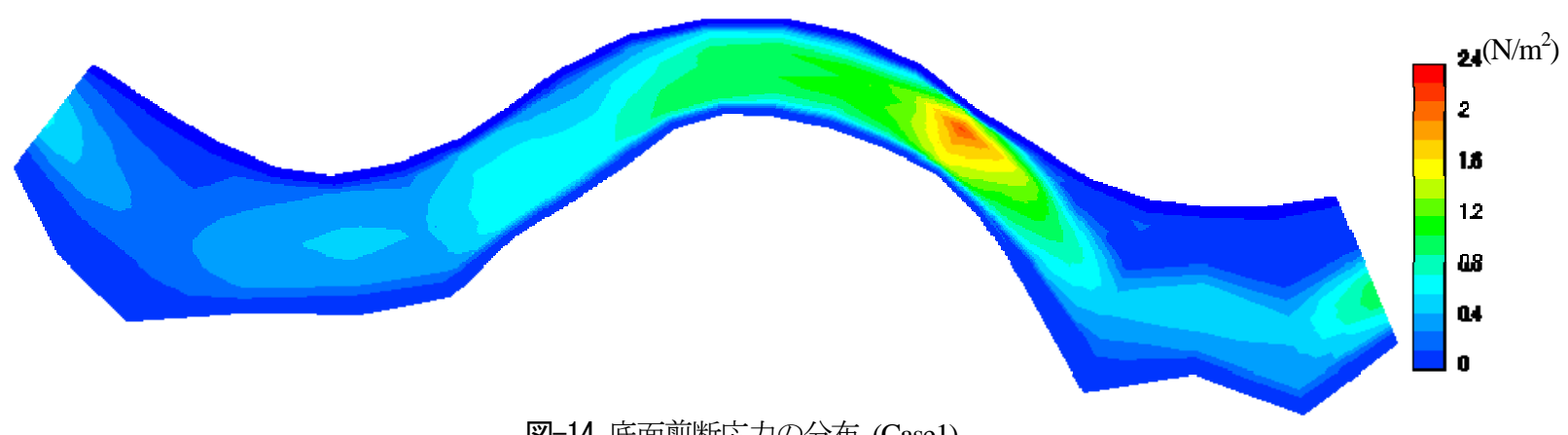

図-14 底面剪断応力の分布 (Case1)



図-15 底面剪断応力の分布 (Case2)

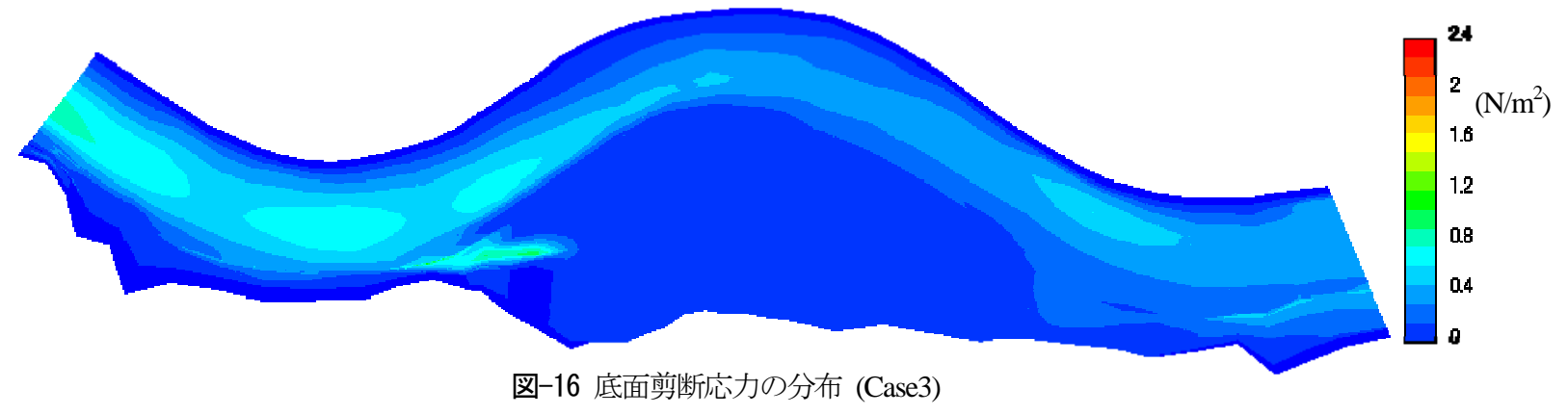

れは，アザメの瀬上流付近の本川の蛇行の影響が，堤防 上の竹林によって弱められたためだと考えられる.

図-11〜13は，アザメの瀬上流(16.0km), 中流(15.8km), 下流(15.6km)における流量ピーク時の流速の横断分布を 示す。上流部において, Case1では本川内で高速流を示 している．これに対して，アザメの瀬を考慮したCase2 では本川での流速は約30\%低減され，堤防越流地点にお いて最大流速を示している. また堤防上に植生を繁茂さ せたCase3では, 本川の流速はCase1に比べて約15\%の減 少に止まっているが，堤防での越流流速はCase2に比心゙ て大幅に減少しており, 瀬内では横断方向にほぼ一様な 流速が示されている. 中流部の15.8kmでは, Case2の堤 防上の流速を除けば各Caseとも上流部と同じ傾向である と言える. 本川での極大流速はCase1に比べてCase2は約 40\%, Case3では約60\%に抑えられているが，極大值の 発生位置はCase1で河道のほぼ中央であるのに対して, アザメの瀬を考慮しているCase2およびCase3では右岸寄 りにシフトしているのが認められる. 下流部においても 流速の極大值はCase1で最も大きく, Case2およびCase3 の約1.8倍まで達している，その発生位置は，Case1でほ ぼ河道中央であるのに対して, Case2とCase3は左岸寄り
になることが示されている．また，Case2とCase3の分布 形はほぼ等しくなっており，上流部堤防上の植生の影響 はほとんど無いと考えられる. 以上の流速の横断分布よ り，アザメの瀬が有ることによって本川での流速は低減 されるが，流心は本川中央部を通らず，特に下流側では 左岸堤防に近づくことが分かった.

\section{（3）底面剪断応力の分布特性}

各ケースの流量ピーク時における底面剪断応力の分 布を図-14 16に示寸.

分布形はアザメの瀬の有無で大きく異なっており， アザメの瀬が存在しないCase1では本川の河道が狭い箇 所で極大值を示していることが分かる.

アザメの瀬を考慮したCase2では，本川ではアザメの 瀬より上流側に極大值が存在している. また, 瀬と本川 とを分けている堤防上に剪断応力の最大值が現れており， 堤防上に沿って流下方向へと延びている. アザメの瀬内 では右岸側で小さく, 堤防付近では本川と同程度の值で あることが分かる。

本川と瀬とを分ける堤防上に竹林を配置したCase3で は，本川ではCase2と同様に，瀬の上流で大きな值を示 


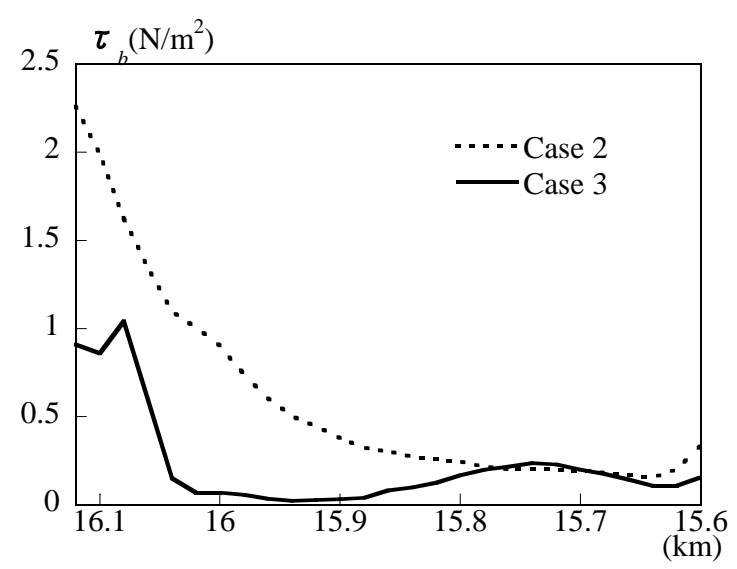

図-17 最大底面剪断応力の流下方向変化

しているが，流下方向には本川の形状に沿って延びてい る. アザメの瀬内では全体的に小さく抑えられている. これは，上流から瀬内へと流れ込む流速が植生帯によっ て抑えられ，Case2に較べて本川を流れやすいためであ ると考えられる.

図-17はアザメの瀬内における最大底面剪断応力の縦 断分布を示したものである. Case2では上流側で大きく 流下寸るに従い減少する傾向に在る. それに対して竹林 を配置したCase3では，竹林帯通過後急激に減少し，下 流側で回復していることが分かる．上流側では竹林帯の 影響が顕著であり約 $1 / 3$ に抑えられているが，下流端で は影響はほとんど無い.

\section{（4）遊水効果}

各ケースの上流付近と下流端の断面通過流量を図-18 に示す. 上流付近の $16.2 \mathrm{~km}$ の通過断面流量は3ケースと もほぼ同様であった。

下流端ではCase2とCase3は同様な分布形をとっており， 植生帯の有無の違いは現れていない. 上流付近の流量と 下流端の流量を比較すると，河道のみのCase1では約 $40 \mathrm{~m}^{3} / \mathrm{s}$ の断面通過流量の減少があるのに対して，アザメ の瀬がある場合は約 $90 \mathrm{~m}^{3} / \mathrm{s}$ の減少が示されている．河道 のみと比較すると約 $50 \mathrm{~m}^{3} / \mathrm{s}$ の貯留効果が見込まれると考 えられる.

\section{4. 結論}

本研究では，自然再生事業が進む佐賀県松浦川のアザ メの瀬を含む流れを，一般座標系を用いた平面2次元非 定常流れの数值シミュレーションによって解析した. 得 られた結果は以下のようである.

1）数值実験の結果, 計画流量ピーク時において, ア ザメの瀬のない現況河道では狭窄部での流速が

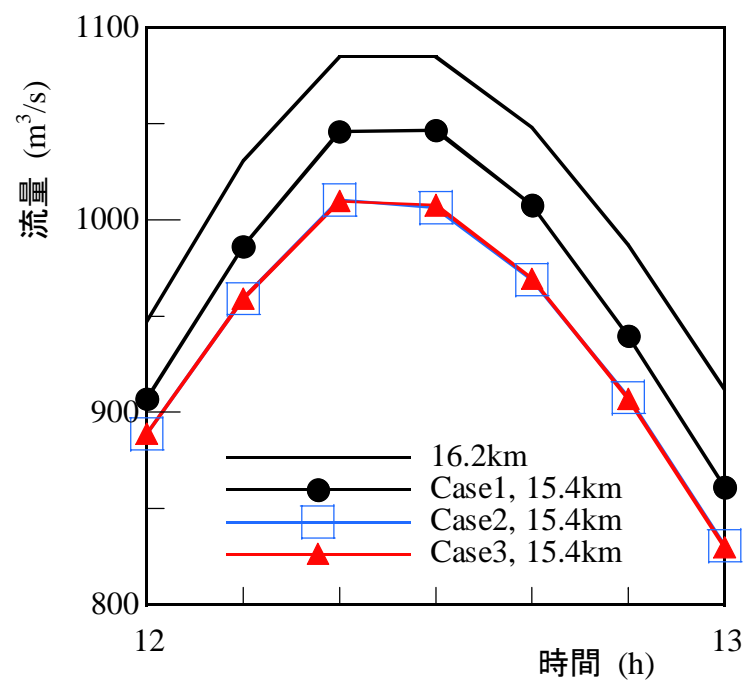

図-18 断面通過流量の時間変化

4. $5 \mathrm{~m} / \mathrm{s}$ に達するのに対して，アザメの瀬が存在す る場合は約半分にまで抑えられる。

2）アザメの瀬が存在する場合，洪水流は河道とアザ メの瀬の境界である堤防の上流部を乗り越えて瀬 内に流入するが，堤防上に竹林が繁茂していると 流入する流速は抑えられ，横断方向に一様に瀬内 を流下する。これに対して植生帯が無い場合は瀬 内に時計回りの一つの循環流を形成し，堤防近傍 の流速は河道とほぼ等しくなることが認められる.

3） アザメの瀬下流端における主流部の流速のピーク 值は現況河道に比べ約60\%に押さえられるが，その 位置は左岸近傍へとシフトしている.

4）アザメの瀬により，本川での底面剪断応力は小さ くなる. 本川と瀬とを仕切っている堤防上に植生 帯が無ければ，堤防上とその左右に大きな剪断応 力が生じる. しかし，竹林帯を配置するとアザメ の瀬内全体の底面剪断応力は小さくなり, 最大で 1/3程度に抑えられる。

謝辞 : 本研究を行うに当たり，国土交通省武雄河川工事 事務所より貴重な資料を提供いただいた。記して謝意を 表す.

\section{参考文献}

1) 国土交通省武雄河川工事事務所：ホームページ (http://www.qsr.mlit.go.jp/takeo/azame/) .

2) 国土交通省武雄河川工事事務所 : アザメの瀬シンポジウム 資料，2004.

3) 長田信寿:一般座標系を用いた平面 2 次元非定常流れの数值 解析, 水工学における計算機利用の講習会講義集, pp.61-76, 1999.

4) 福岡捷二, 藤田光一 : 洪水流に及ぼす河道内樹木群の水理 的影響，土木研究所報告，第180号-3, pp.129-190， 1990.

(2006. 9. 30受付) 